\title{
Entre gregos e romanos: história e literatura no Mundo Clássico
}

\author{
Ana Teresa Marques Gonçalves[1]
}

\begin{abstract}
Resumo
A escrita da história também foi pensada pelos autores antigos. A relação estabelecida entre história e literatura, discutida em muitos trabalhos contemporâneos, ganha novos prismas de análise quando se acrescentam as reflexões de autores clássicos, gregos e romanos, que produziram obras nas quais percebemos a preocupação com a arte do bem escrever. A persuasão, a beleza e a verossimilhança foram características que marcaram a produção em prosa e poesia na Antiguidade Clássica e continuam sendo importantes na discussão atual a respeito do saber histórico, como procuramos defender neste artigo.

Palavras-chave: história; literatura; Antiguidade.
\end{abstract}

\section{Entre griegos y romanos: la historia y la literatura en el mundo clásico}

\section{Resumen}

La escritura de la historia también fue estudiada por los autores antiguos. La relación entre la historia y la literatura, discutida en muchas obras contemporáneas, gana nuevas perspectivas de análisis cuando se agregan las reflexiones de los autores clásicos, griegos y romanos, que escribieron obras en las que percibimos la preocupación por el arte de la buena escritura. La persuasión, la belleza y la verosimilitud fueron características que marcaron la producción de prosa y poesía en la Antigüedad clásica y siguen siendo importantes en la discusión actual acerca del conocimiento histórico, lo que intentaremos exponer en este artículo. Palabras clave: historia; literatura; Antigüedad.

\section{Among Greeks and Romans: history and literature in the classical world}

\begin{abstract}
The writing of history was also studied by the ancient authors. The relationship between history and literature, discussed in many contemporary researches, can be analyzed from different angles when you add the reflections of classical authors, Greek and Roman, who produced works in which we perceive the concern for the art of good writing. Persuasion, beauty, and verisimilitude were characteristics that defined the writing of prose and poetry in Classical Antiquity and remain important in the current discussion about the historical knowledge, as we seek to show in this article.
\end{abstract}

Keywords: history; literature; Antiquity.

\section{Chez les Grecs et les Romains: l'histoire et la littérature dans le monde classique}

\section{Résumé}

Les anciens auteurs ont aussi pensé à comment écrire l'histoire. La relation entre l'histoire et la littérature, abordée dans nombreuses études contemporains, ont gagné nouvelles perspectives avec des réflexions d'auteurs classiques, grecs et romains qui ont produit d'œuvres oú on voit la préoccupation avec lart de bien écrire. la persuasion, la beauté et de vraisemblance ont marqué la production en prose et en poésie dans l'antiquité classique, et restent importantes dans les discussions actuelles sur le savoir historique, idée que nous défendons dans cette article.

Mots clés: histoire; littérature; Antiquité. 

a busca de se comunicar com seus contemporâneos e com os pósteros, os homens na Antiguidade produziram inúmeros vestígios arqueológicos e textuais que nos permitem conhecer um pouco sobre sua forma de vida, suas crenças, seus temores, seus sentimentos, suas sensibilidades, suas maneiras de relatar as experiências e suas projeções. Muitas dessas informações encontram-se embaladas por textos que passamos a identificar como integrados ao gênero histórico. Neste artigo, debruçamo-nos sobre as múltiplas formas como a escrita da história, uma arte e uma técnica no mundo antigo que se perfazia num eterno fazer e refazer de cunho literário, foi pensada por alguns autores clássicos e como essa elaboração textual e retórica vem sendo continuamente repensada por autores atuais.

Dionísio de Halicarnasso ${ }^{1}$ foi um autor que viveu em Roma no século I a.C. Integrou um famoso círculo literário, formado ao redor das famílias dos Tuberão e dos Élio, e foi professor de retórica na capital, onde ensinava grego e escrevia obras que tinham uma dupla finalidade: demonstrar como os romanos chegaram a ser os senhores do mundo e divulgar os feitos desse povo para os leitores gregos. Nas palavras de Julio Pallí Bonet, dessas duas premissas vem o interesse de Dionísio em:

Mostrar à gente grega que o desenvolvimento do poder romano seria obra da virtude e não da sorte, e de sugerir que na glória de Roma o homem grego pudesse festejar sua própria glória, pois como afirma nas Antiguidades Romanas [I.89] Roma poderia considerar-se uma cidade grega. ${ }^{2}$

À sua função de historiador das grandes conquistas romanas, Dionísio juntou a produção de obras sobre o ensino da retórica e a chamada crítica literária, ou seja, a formulação de manuais dedicados à arte de produzir boas obras literárias, que deveriam tanto ser lidas quanto ouvidas em declamações públicas e/ou privadas.

Dionísio parece-nos o personagem ideal para iniciar este artigo, pois em sua produção demonstra que, no mundo antigo clássico, História e Literatura eram saberes absolutamente amalgamados. Retomando a obra de icônicos oradores gregos, como Lísias, Demóstenes e Isócrates, Dionísio defende, no tratado Sobre a Composição Estilística, dedicado ao discípulo Rufo Metilio, que tudo o que é escrito e/ou falado deve ser feito seguindo-se as normas da peithós, da persuasão, do convencimento, e que, para atingi-la, o orador deve se preocupar principalmente com a linguagem, com a disposição das palavras, suas diversas combinações possíveis, as estruturas das orações e o ritmo, no que vai ser definido como a "música da linguagem". Nos capítulos 21 a 24 da obra, Dionísio chega a indicar uma harmonia do discurso que, ao mesmo tempo, relacionava e diferenciava prosa e poesia. Citando Homero, Heródoto, Tucídides, Platão, Safo, Píndaro, Eurípides e Simônides, congrega vários estilos para demonstrar que a produção textual é, antes de tudo, produto de aplicação

'Cidade localizada no extremo sul da Ásia Menor

2Julio Pallí Bonet, "Introducción", In: Dionísio de Halicarnasso, Sobre la Composición Estilística, Tradução de Julio Pallí Bonet, Barcelona, PPU, 1991, p. 11.

3/dem, Ibidem, p. 14. 
de uma arte (em latim: ars; em grego: thecnè), isto é, um conjunto de habilidades que precisam ser sempre aplicadas e trabalhadas.

Assim, produtor de textos seria aquele que teria por obrigação do ofício a necessidade de refazer frequentemente a sua obra, procurando as melhores palavras, a mais adequada combinação de termos, o mais preciso encadeamento de argumentos, a busca da lógica discursiva capaz de persuadir. Para Dionísio, cada autor deveria se preocupar com o gênero escolhido para exercitar sua arte, mas a beleza da produção literária se estribava essencialmente na harmonia e na simetria da conexão das palavras. Segundo ele, três princípios básicos precederiam todos os gêneros: conhecer as palavras que se quer usar; saber como estas podem ser ajustadas para que destaquem a harmonia do que é dito; e julgar se é necessária alguma modificação, mediante adição, supressão e/ou variação do material empregado na composição. Desse modo, qualquer obra escrita deveria possuir duas finalidades básicas: a beleza e o prazer. Ressalta Dionísio nos capítulos 10 e 11 da obra citada: ${ }^{4}$

Parece-me que os dois objetivos fundamentais que devem perseguir os autores em verso ou em prosa são o prazer e a beleza. O ouvido reclama um e outro, e o mesmo ocorre com os olhos [...] Não creio que ninguém considere incoerente se proponho dois objetivos e distingo beleza do prazer, nem estranhe se preciso que uma passagem possa estar composta agradavelmente, mas sem beleza, ou com beleza, mas sem agrado [...] Tucídides e Antifonte de Ramnunte ${ }^{5}$ alcançaram, por Zeus, mais que nenhum outro a beleza da composição estilística [...], mas não são particularmente agradáveis. O historiador Ctesias de $\mathrm{Cnido}^{6} \mathrm{e}$ Xenofonte, o Socrático, ${ }^{7}$ põem todo o agrado possível em seu estilo, mas não a beleza necessária [...] Porém, em Heródoto, a composição possui estas duas qualidades: agrado e beleza. Para lograr prazer e beleza no estilo, os quatro fatores mais gerais e mais poderosos são: a melodia, o ritmo, a variedade e a adequação ou conveniência, que acompanha os outros três. Coloco no prazer o esplendor, a graça, a eufonia, a doçura, a persuasão e outras qualidades semelhantes; na beleza, a grandeza, a gravidade, a nobreza de linguagem, a dignidade, a emoção e outras qualidades semelhantes [...] Estes são, pois, os fins que perseguem os escritores sérios, autores de poemas épicos, poesias líricas ou obras na chamada prosa $[. . .]^{8}$

\footnotetext{
${ }^{4}$ Trabalhamos com as seguintes traduções de obras antigas: Aristóteles, A poética, Tradução de Valentin García Yebra, Madrid, Gredos, 1974; Idem. Retórica das paixões, Tradução de Ísis Borges B. da Fonseca, São Paulo, Martins Fontes, 2000; Demétrio, Sobre el estilo, Tradução de José García López, Madrid, Gredos, 1996; Dionísio de Halicarnasso, Sobre la composición estilística, Tradução de Julio Pallí Bonet, Barcelona, PPU, 1991; Heródoto, Histórias, Tradução de Mário da Gama Kury, Brasília, Editora da UnB, 1988; Longino, Sobre lo sublime, Tradução de José García López, Madrid, Gredos, 1996; Paladas de Alexandria, Epigramas, Tradução de José Paulo Paes, São Paulo, Nova Alexandria, 1993; Tucídides, História da Guerra do Peloponeso, Tradução de Mário da Gama Kury, Brasília, Editora da UnB, 1987.

${ }^{5}$ Orador do século V a.C., contemporâneo de Górgias, representou em suas obras uma harmonia austera. ${ }^{6}$ Historiador e médico a serviço do rei persa Artaxerxes, no final do $V$ século a.C., escreveu uma História da Pérsia em 23 livros, uma História da India e uma Geografia.

${ }^{7}$ Muito interessante essa referência ao fato de Xenofonte ter sido um dos discípulos de Sócrates, portanto, um continuador de seu estilo literário e filosófico.

${ }^{8}$ Dionísio de Halicarnasso, Sobre la composición estilística, 10. 2-4; 11.1-3.
} 
Assim, para Dionísio, o escritor que opta por escrever relatos históricos deveria se submeter às mesmas finalidades de qualquer outro autor na Antiguidade: buscar a produção de um texto agradável aos olhos e aos ouvidos. A conveniência do que é dito é importante, mas atrelada aos outros três fatores que regem a arte da escrita. Dever-se-ia buscar o ritmo, a melodia e a variedade para assegurar a atenção do público ouvinte e/ou leitor. A busca pelo que realmente aconteceu, típico do gênero histórico, como atentou Aristóteles na Poética, seria consequência do modelo de relato eleito pelo escritor, mas deveria se submeter às regras mais amplas da retórica. Relembremos a famosa passagem aristotélica sobre as finalidades diferenciadas da poesia e da história:

Pelas precedentes considerações se manifesta que não é ofício de poeta narrar o que aconteceu; é sim o de representar o que poderia acontecer, quer dizer: o que é possível segundo a verossimilhança e a necessidade. Com efeito, não diferem o historiador e o poeta, por escreverem verso ou prosa [pois que bem poderiam ser postas em verso as obras de Heródoto, e nem por isso deixariam de ser história, se fossem em verso o que eram em prosa], diferem sim em que diz umas coisas que sucederam, e outro as que poderiam suceder. Por isso a poesia é algo de mais filosófico [indicações de modo de vida aplicáveis] e mais sério do que a história, pois refere aquela principalmente o universal, e esta o particular. Por referir-se ao universal entendo eu atribuir a um indivíduo de determinada natureza pensamentos e ações que, por liame de necessidade e verossimilhança, convêm a tal natureza; e ao universal, assim entendido, visa à poesia, ainda que dê nomes aos seus personagens; particular, pelo contrário, é o que fez Alcibíades ou o que lhe aconteceu. ${ }^{9}$

Desse modo, o gênero histórico, como qualquer outra forma de relato que deveria atender às prerrogativas da arte de escrever, teria de buscar a beleza e o agrado na forma e no conteúdo. Atendo-se à verossimilhança, ao possível de ter ocorrido, ao captável pela imaginação, a história partiria do particular para o geral. Relataria casos específicos, visando modelar exempla. Uniria de forma atávica passado, presente e futuro, numa cadeia causal que conduziria o leitor/ouvinte pelo interessante relato do ocorrido. De igual maneira, caberia ao historiador, enquanto mestre da linguagem, escolher um bom tema, as melhores palavras e lançar mão de seu repertório de imagens para produzir a mais adequada narrativa.

O homem antigo sabia perfeitamente que, ao ler e/ou ouvir um texto, de qualquer gênero, imagens se formariam em sua mente, permitindo que o lido ganhasse contornos e sentidos. Por isso, sempre foram tão caros na Antiguidade os processos de aemulatio ou imitatio (em grego, mímesis) na formação artística, isto é, a inspiração em modelos já comprovados de eficácia. Como afirma Donald A. Russell, a imitação foi um elemento essencial na composição literária na Antiguidade Clássica, mas não uma emulação plagiária. A imitação era

${ }^{9}$ Aristóteles, A poética, IX.50.1. 
uma prática seletiva, adaptativa e criativa. Dever-se-ia seguir os modelos e a tradição, visto que a imitação não era de um autor, mas das boas qualidades abstratas alcançadas por uma obra. ${ }^{10}$

\section{A busca pelo que realmente aconteceu, típico do gênero histórico, como atentou Aristóteles na Poética, seria consequência do modelo de relato eleito pelo escritor}

A autoria e a citação eram práticas definidas por cânones muito diversos dos nossos. Como nos recorda Claude Calame, a atribuição de um produto poético a uma autoridade designada por um nome próprio dependeria de um procedimento enunciativo, ${ }^{11}$ ou seja, o autor se apresentava como responsável por aquele discurso e sofreria as consequências advindas de sua enunciação. Inserir numa obra uma determinada passagem de outro autor era uma demonstração de conhecimento, de respeito à tradição, uma homenagem ao passado de onde vinham os melhores cânones a serem seguidos e uma recuperação mnemônica, pois a principal arma da memória seria a repetição constante.

Dessa forma, além da preocupação com a forma da narrativa, o historiador antigo preocupar-se-ia com o objeto a ser descrito. Demétrio de Falero, ${ }^{12}$ na obra Sobre o Estilo, ressalta a importância da escolha do tema a ser trabalhado:

A elevação do estilo também depende dos temas tratados. Por exemplo, se $\mathrm{o}$ assunto é uma batalha grande e famosa por terra ou por mar, ou se trata do céu ou da terra. Pois aquele que ouve um tema elevado pensa, enganado, que o orador também fala com elevação. É necessário, pois, considerar não apenas as coisas que são ditas, mas como são ditas. Já que também alguém que narra grandes temas de forma inexpressiva pode atuar de modo inapropriado ao elevado do assunto. Há escritores veementes, como Teopompo, que narram muito pobremente temas admiráveis. $\mathrm{O}$ pintor $\mathrm{Nícias}^{13}$ era aficionado em dizer que uma parte não pequena da arte pictórica estava em escolher para pintar um tema muito importante e em não cortar sua arte em pequenas peças, como pequenos pássaros ou flores, mas lutas com cavalaria e combates navais, onde um tem a possibilidade de mostrar figuras de cavalos, alguns correndo, outros empinando-se, outros ainda caindo ao solo, e inumeráveis arqueiros e cavaleiros

\footnotetext{
${ }^{10}$ Donald A. Russell, "De Imitatione", In: David West; Tony Woodman, Creative imitation and Latin Literature, Cambridge, Cambridge University Press, 2007, p. 1-16.

"Claude Calame, "Identités d’auteur à léxemple de la Grèce Classique: signatures, énonciations, citations", In: Claude Calame; Roger Chartier, Identités d'auteur dans l'Antiquité et la tradition européenne, Paris, Jérome Millon, 2004, p. 12. ${ }^{12}$ Autor que viveu entre os séculos III e II a.C.

${ }^{13}$ Nícias de Atenas foi discípulo de Antídoto, que pintou estátuas para Praxíteles no IV século a.C.
} 
derrubados de suas montarias. Pois ele acreditava que o tema mesmo era parte da arte pictórica, como os mitos o são da arte poética. Assim, não é de se admirar se também nos discursos a elevação surge de temas elevados. ${ }^{14}$

Nessa perspectiva dos autores antigos que refletem sobre a arte da escrita na Antiguidade, a escolha de um bom tema permitiria ao autor demonstrar toda a sua potencialidade estilística e conquistar a plateia. Tal concepção manteve-se constante na arte literária, tanto que reaparece na obra Sobre $o$ sublime, de Cássio Longino, no século I d.C. Todavia, esse autor acrescenta uma informação fundamental: após escolher o tema e as melhores palavras para relatá-lo, de acordo com o gênero eleito, cabia ao autor apresentar os argumentos em ordem de importância, tornando o relato uma sobreposição de elementos interconectados apresentados de forma segura, seletiva, linear e cronológica. Afirma Longino:

Posto que a todas as coisas estão associados por natureza certos elementos inerentes à substância de cada uma, necessariamente para nós a causa do sublime seria o poder de escolher sempre dos elementos inerentes os mais importantes e fazê-los formar, mediante uma sobreposição sucessiva, como que um só corpo. Pois este procedimento permite que se ganhe o ouvinte com a eleição das idéias, e depois com a acumulação das que foram selecionadas. Assim, Safo assinala em todos os casos as emoções que acompanham a loucura amorosa, partindo dos sintomas e da verdade mesma da paixão. Mas como ela demonstra a sua destreza na escrita? Em seu poder para eleger primeiro os fatores que mais sobressaem e os mais importantes, para uni-los depois uns aos outros [...] Do mesmo modo, o poeta na descrição das tormentas escolhe entre os fenômenos que as acompanham os mais violentos. ${ }^{15}$

Caberia ao autor, dessa forma, eleger os argumentos mais importantes, as imagens que pretendia gerar no público, as emoções que necessitaria causar, a partir da disposição dos assuntos. Mais importante que dar crédito ao utilizado na elaboração do texto seria convencer o público, usando a boa performance do orador e a predisposição da plateia. Mais uma vez, é Aristóteles quem atenta para isso na obra Sobre a retórica:

Com que argumentos se deve, pois, persuadir e dissuadir, louvar e censurar, acusar e defender-se, e que opiniões e premissas são úteis para as respectivas provas, é o que foi exposto, porque em torno desses argumentos e a partir deles se formam os entimemas, que se referem particularmente, por assim dizer, a cada gênero dos discursos [...] Importa muito para a persuasão, sobretudo, nas deliberações, e depois nos processos, que o orador se mostre sob certa aparência e faça supor que se acha em determinadas disposições a respeito dos ouvintes e, além disso, que

${ }^{14}$ Demétrio de Falero, Sobre o estilo, II.75-76.

${ }^{15}$ Longino, Sobre o sublime, X.1-4. 
estes se encontrem em semelhantes disposições a seu respeito [...] Com efeito, para as pessoas que amam, as coisas não aprecem ser as mesmas que para aqueles que odeiam, nem para os dominados pela cólera, as mesmas que para os tranquilos; mas elas são ou totalmente diferentes ou de importância diferente; aquele que ama tem por certo que a pessoa sob julgamento ou não pratica ato injusto ou comete delitos de pouca importância, e aquele que odeia tem por certo o contrário [...] As paixões são todos aqueles sentimentos que, causando mudança nas pessoas, fazem variar seus julgamentos, e são seguidos de tristeza e prazer, como a cólera, a piedade, o temor e todas as outras paixões análogas, assim como seus contrários. ${ }^{16}$

\section{A memória usada e construida é campo \\ do imaginário, no sentido do eidolon,do duplo, da imagem formada na mente e rememorada na hora da escrita}

Dessa maneira, cada ser humano, ao ler ou ouvir um relato, iria imaginá-lo de uma forma diversa, dependendo da paixão pela qual se encontrava acometido. É das paixões do público que devem advir os argumentos retóricos para o bom orador na visão aristotélica. ${ }^{17}$ As palavras causam sentimentos, despertam emoções desde a Antiguidade. Por isso, o autor deveria escolher bem os termos que iria utilizar no seu relato, para gerar um determinado comportamento nos leitores/ouvintes. Como relembra Paul Ricoeur, a partir da análise das obras platônicas e aristotélicas, todo relato deve seguir uma ordem de entendimento e, ao mesmo tempo, usar a rememoração e permitir a inserção do que é narrado na memória. ${ }^{18}$ A memória usada e construída é campo do imaginário, no sentido do eidolon, do duplo, da imagem formada na mente e rememorada na hora da escrita. Na maior parte das vezes, as citações eram feitas de memória, sem o recurso direto a um exemplar da obra citada. De igual maneira, os discursos diretos inseridos na narrativa, que teriam sido proferidos pelos personagens retratados, eram construídos como obras de peroração retórica, isto é, o autor criava o discurso a partir de um mote, de uma ideiaforça que teria conduzido a fala do personagem e, a partir dela, criava o que o personagem deveria ter dito, sem qualquer perda de objetividade discursiva dentro dos cânones antigos, visto que a beleza e o agrado continuavam dirigindo a produção narrativa.

${ }^{6}$ Aristóteles, Sobre a retórica, I.1-25

${ }^{17}$ Idem, Ibidem, XI.30.

${ }^{18}$ Paul Ricoeur, La memória, la historia, el olvido, Madrid, Trotta, 2003, p. 21-22. 
Lembremo-nos da insistência de Tucídides, na História da Guerra do Peloponeso, em afirmar que não iria relatar as palavras realmente pronunciadas, visto que os discursos proferidos o eram em assembleias, sem relator nem secretário. Como define Jeanne-Marie Gagnebin, ${ }^{19}$ Tucídides insiste nesse ponto porque ele pretendia ressaltar uma impossibilidade mais essencial: não se poderia acreditar plenamente na memória para garantir a fidelidade do relato à realidade. Em oposição à tradição anterior, a memória em Tucídides não assegurava a autenticidade do relato. Ele exigia uma reconstituição crítica dos acontecimentos, cujos critérios seriam a verossimilhança da situação e a pertinência das palavras pronunciadas. Afirma Tucídides:

Tais discursos, portanto, são reproduzidos com as palavras que, no meu entendimento, os diferentes oradores deveriam ter usado, considerando os respectivos assuntos e os sentimentos mais pertinentes à ocasião em que foram pronunciados. ${ }^{20}$

A imitação criativa permaneceria, desse modo, em ação. Significa, a nosso ver, que Tucídides escreveu os seus numerosos e famosos discursos segundo a ordem das razões históricas, não como um cronista confiando em suas lembranças. Seu texto foi construído a partir da conveniência, da escolha prévia de um material que não é sequer mencionado, da coerência e da interpretação. Assim, a linguagem sempre foi a principal ferramenta de um literato, de um escritor, de um autor, de um historiador. Já o sabia Platão. No Crátilo, ele construiu o seguinte diálogo:

Sócrates: Vejamo, Crátilo, se há meio de nos entendermos. Não admites que o nome é uma coisa, e que o objeto ao qual pertence o nome é outra coisa?

Crátilo: Sim.

Sócrates: A justeza de um nome, segundo nós, consiste em fazer ver a natureza da coisa. Achamos esta definição suficiente?

Crátilo: Na minha opinião, ela o é perfeitamente, Sócrates. ${ }^{21}$

Todas as palavras seriam, assim, justas para Platão e procederiam unicamente da mistura das letras, que possuiria cada uma um valor semântico definido por convenção e cultura. ${ }^{22}$ Caberia ao autor do texto usá-las com sentido, de forma adequada, respeitando convenções, práticas culturais e hábitos sociais. Nas sociedades antigas, a escrita tinha uma finalidade bastante diversa da fornecida a ela pelo mundo moderno. Hoje, se escreve para esquecer; no passado, grafava-se para recordar. Basta observar as obras homéricas e seus múltiplos recursos mnemônicos para facilitar a cantoria dos aedos e dos rapsodos. Escrevia-se para releitura constante, para se reter uma informação até que

\footnotetext{
9 Jeanne-Marie Gagnebin, Sete aulas sobre linguagem, memória e história, Rio de Janeiro, Imago, 1997, p. 32.

${ }^{20}$ Tucídides, História da Guerra do Peloponeso, 1.22.

21Platão, Crátilo, 428e; 430a.

${ }^{22}$ Carl Herrenschmidt, "O todo, o enigma e a ilusão", In: Jean Bottéro; Ken Morrison, Cultura, pensamento e escrita, São Paulo, Ática, 1995, p. 133-134.
} 
ela pudesse ser reproduzida sem o auxílio dos rolos e dos códices. ${ }^{23}$ Como também nos lembra Jeanne-Marie Gagnebin, no livro Lembrar, Escrever, Esquecer, ${ }^{24}$ no mundo antigo escrevia-se para lembrar, para inserir um feito na memória social, enquanto no mundo contemporâneo exerce-se a escrita para se olvidar; o ato da escrita possibilita hoje que se passe a outro assunto, que se possa arquivar um pensamento para mais tarde. Na Antiguidade, a escrita desejava

Perpetuar o vivo, mantendo sua lembrança para as gerações futuras, mas só pode salvá-lo quando o codifica e o fixa, transformando sua plasticidade em rigidez, afirmando e confirmando sua ausência [...] A memória dos homens se constrói entre dois pólos: o da transmissão oral viva, mas frágil e efêmera, e o da conservação pela escrita, inscrição que talvez perdure por mais tempo, mas que desenha o vulto da ausência [...] O apelo do presente, da vida no presente, também exige que o pensamento saiba esquecer. ${ }^{25}$

Para Eric A. Havelock, a composição oral do que nos chegou em suportes literários não deve ser pensada como matéria de improviso. Era, por definição, uma composição rítmica, logo, poética. Os termos "poético" e "poesia" equivalem em grego a letrado e à arte da escrita, respectivamente. Escrevia-se, decorava-se e pronunciava-se. Poesia seria o nome de um uso ideal da linguagem, superior em certos aspectos aos poderes expressivos da prosa, usada como linguagem de informação e de instrução, típica de gêneros como a história e a lei. ${ }^{26}$

Greg Woolf, em artigo intitulado "Literacy or Literacies in Rome?", defende o uso do plural para caracterizar o ato da produção de obras escritas devido a sua diversidade, finalidade e gêneros múltiplos. Os usos da escrita foram plurais. Só para nos restringirmos ao Império Romano, damos conta da existência de diversos suportes que caracterizam o letramento social: papiros, tabletes de bronze e cobre, inscrições rituais em pedra e madeira, selos, assinaturas e mensagens em potes de cerâmica, ostraka, grafitos, entre outras formas epigráficas. ${ }^{27}$ Em termos de gêneros estilísticos, restaram-nos epístolas, panegíricos, obras históricas, obras filosóficas, obras apologéticas, tratados, homilias, manuais de sedução, manuais militares, manuais de agricultura, autobiografias, biografias diversas, breviários, epigramas, entre tantas outras formas de se comunicar.

Ruth Webb, em sua obra Ekphrasis, imagination and persuasion in ancient rhetorical: theory and practice, demonstra como se criou uma cultura retórica no período romano bastante rica e diversificada, pelo interesse crescente pela estética e pela prática constante da persuasão. A primazia do visual geraria nos autores a necessidade de criarem relatos ricos em imagens, utilizando, portanto,

\footnotetext{
${ }^{23}$ Roger Chartier, Cultura escrita, literatura e história, Porto Alegre, Artmed, 2001, p. 13.

24Jeanne-Marie Gagnebin, Lembrar, escrever, esquecer, São Paulo, Editora 34, 2006, p. 45.

25/dem, Ibidem, p. 11-12.

${ }^{26}$ Eric A. Havelock, A revolução da escrita na Grécia e suas conseqüências culturais, São Paulo, Editora da Unesp, 1996, p. 13; Eric A. Havelock; José Trindade Santos; Maria Leonor Santa Bárbara, A musa aprende a escrever: reflexões sobre a oralidade e a literacia da Antiguidade ao presente, Lisboa, Gradiva, 1996, p. 96.

${ }^{27}$ Greg Woolf, "Literacy or literacies in Rome?", In: William A. Johnson; Holt N. Parker, Ancient literacies, Oxford: Oxford University Press, 2009, p. 46-68
} 
todos os aspectos viáveis do imaginário e do emocional. O bom relato deveria possuir enargeia, vivacidade, qualidade da linguagem usada que apelava antes de tudo para a imaginação da audiência, ${ }^{28}$ para captar e manter a atenção e o interesse do público consumidor das ideias expostas. A diegesis, descrição, tinha de inspirar o ouvinte/leitor, tinha de gerar efeitos em qualquer gênero escolhido para mediar a elaboração da narrativa. ${ }^{29}$

\section{Só para nos restringirmos ao Império Romano, damos conta da existência de diversos suportes que caracterizam o letramento social}

Assim, a retórica era uma arte, um conjunto de técnicas de disposição de conteúdo e de reformulação de memórias. $\mathrm{O}$ discurso construído buscava invadir e se estabelecer no campo do compreensível e do memorável, incluindo detalhes e movendo o expectador. Cabia ao escritor realizar a mediação entre a realidade material e fatual e a linguagem disponível. Mais que a beleza ornamental, dever-se-ia optar pela acuidade dos ditos, entre o que poderia ser retomado pelos contemporâneos e pelos pósteros. Consideremos os trabalhos de Averil Cameron. Em dois textos diversos, no capítulo "History and the individuality of the historian: the interpretation of late Antiquity", do livro The past before us: the challenge of historiographies oflate Antiquity, editado por Carole Straw e Richard Lim, e na coletânea History as text: the writing of ancient history, por ela editada em 1990, aventa as intenções autorais que modelam os gêneros a partir da relação estabelecida entre história e retórica, questionando-se sobre a aplicação dos termos "obras literárias" e "obras historiográficas" no estudo dos relatos antigos. Apoiando-se no conceito de textualidade, Cameron ressalta o aspecto da convicção religiosa como seminal para a compreensão das obras, por exemplo, da Antiguidade tardia, mas destaca que elementos individuais marcam os relatos de forma mais constante que cânones instituídos, que podem ser asseverados de forma bem mais indelével na produção literária. Os historiadores antigos partem dos fatos, mas usam sua imaginação e sua inquirição para relatá-los. Mesclam imaginação, emoção e memória na produção de suas narrativas. ${ }^{30}$

George A. Kennedy nos legou uma obra já clássica sobre a redisposição e a reapropriação das regras da retórica antiga pagã elaborada pelos autores cristãos. Trata-se de Classical Rhetoric and its Christian and secular tradition from ancient to modern times, uma obra de 1998. Nela, Kennedy disserta sobre a

\footnotetext{
${ }^{28}$ Ruth Webb, Ekphrasis, imagination and persuasion in ancient rhetorical: theory and practice, Surrey, Ashgate, 2009, p. 88.

29/dem, Ibidem, p. 37.

${ }^{30}$ Averil Cameron, Christianity and the rhetoric of empire: the development of Christian discourse, Berkeley, University of California Press, 1994; Idem, "History and the individuality of the historian: the interpretation of late Antiquity", In: Carole Straw; Richard Lim, The past before us: the challenge of historiographies of late Antiquity, Belgium, Brepols, 2004, p. 69-77; Averil Cameron, History as text: the writing of ancient history, London, The University of North Carolina Press, 1990.
} 
Progymmasmata, ou seja, os exercícios preliminares que marcariam a educação grega e romana. Dessa maneira, a retórica seria filha e devedora da paideia. Os autores aplicariam as regras retóricas a partir do que aprenderiam com seus professores e retores. ${ }^{31}$

Tão controverso quanto os de literatura, cultura e identidade, o conceito de representação envolve as condições de possibilidade do discurso histórico enquanto discurso de uma prática disciplinar específica, comprometida com a produção de um conhecimento denominado de histórico. ${ }^{32}$ Etimologicamente, representação provém da forma latina repraesentare, isto é, fazer presente ou apresentar de novo. Fazer presente alguém ou alguma coisa ausente, inclusive uma ideia, por intermédio da presença de um objeto. ${ }^{33}$ É nesse mesmo sentido que representação aparece na obra de Carlo Ginzburg, Olhos de madeira: nove reflexões sobre a distância: "A representação faz às vezes da realidade representada e, portanto, evoca a ausência; por outro lado, torna visível a realidade representada, e, portanto, sugere a presença" ${ }^{34}$ E também na de Roger Chartier, À beira da falésia: a história entre certezas e inquietudes:

De um lado, a representação manifesta uma ausência, o que supõe uma clara distinção entre o que representa e o que é representado; de outro, a representação é a exibição de uma presença, a apresentação pública de uma coisa ou de uma pessoa. ${ }^{35}$

As representações adquirem sentido quando compostas no interior de um mesmo imaginário. Hoje podemos ter grandes dificuldades para interpretar o surgimento de mulheres aladas nos arcos do triunfo romanos, mas os habitantes do Império, que compartilhavam o imaginário de sua época e conheciam os significados de suas representações, não teriam grandes dificuldades de perceber que aquelas mulheres com asas, as niké ou vitórias, simbolizavam o fato de aquele arco ter sido construído para comemorar uma batalha vencida, uma vitória militar expressiva, a qual devia ser sempre recordada como um grande feito daquela sociedade. O imaginário de uma sociedade também é uma construção e uma reconstrução humana.

Para Roger Chartier, os homens se percebem e essa autopercepção constitui sua identidade. Mas a percepção se dá no campo das representações coletivas, do imaginário compartilhado por um grupo, num espaço e num tempo específicos. A noção de representação coletiva, por ele adotada, permite que se analisem os conflitos que surgem no interior de uma dada sociedade, a fim de suas representações serem consideradas as mais adequadas para aquela comunidade naquele momento. As sociedades são constituídas por diferentes grupos, que manifestam visões de mundo diferenciadas. Essas visões de mundo hierarquizam as representações:

${ }^{31}$ George A. Kennedy, Classical rhetoric and its Christian and secular tradition from ancient to modern times, London, The University of North Carolina Press, 1998.

${ }^{32}$ Francisco J. C. Falcon, "História e representação", Revista de História das /déias, vol. 21, São Paulo, 2000, p. 87-126. 33/dem, História cultural: uma nova visão sobre a sociedade e a cultura, Rio de Janeiro, Campus, 2002, p. 91.

${ }^{34}$ Carlo Ginzburg, Olhos de madeira: nove reflexões sobre a distância, São Paulo, Companhia das Letras, 2001, p. 85.

${ }^{35}$ Roger Chartier, A beira da falésia: a história entre certezas e inquietudes, Porto Alegre, Editora da UFRGS, 2002, p. 74. 


\begin{abstract}
Uma dupla via é assim aberta: uma que pensa a construção das identidades sociais como resultando sempre de uma relação de força entre as representações impostas por aqueles que têm poder de classificar e de nomear e a definição, submetida ou resistente, que cada comunidade produz de si mesma; a outra que considera o recorte social objetivado como a tradução do crédito concedido à representação que cada grupo faz de si mesmo, portanto, à sua capacidade de fazer com que se reconheça sua existência a partir de uma exibição de unidade. ${ }^{36}$
\end{abstract}

As representações são fruto de lutas e de consensos, de conflitos e de articulações no interior das comunidades. Para Georges Balandier, as visões de mundo estão hoje embaralhadas e o imaginário é apenas outra forma de organização da experiência humana. ${ }^{37}$ No capítulo "As encruzilhadas do imaginário", do livro $O$ Dédalo: para finalizar o século XX, Balandier discute como empregar a noção de imaginário num mundo onde o real e o virtual estão cada vez mais amalgamados. No Brasil, onde personagens virtuais, por vezes, são utilizadas para apresentar programas de televisão, é fácil entender as premissas do autor. As fronteiras entre real e imaginado se esfumaçam, num livro cujo título "O Dédalo" se refere a uma personagem mitológica grega que teria construído o labirinto de Cnossos, palácio da ilha de Creta, onde havia sido enclausurado o Minotauro. Para Balandier, estamos finalizando o século XX no meio de um grande labirinto, como o construído por Dédalo: "As aparências compõem o mundo como uma espécie de labirinto de espelhos onde é impossível caminhar sem erros nem errância".38

O processo de identificação também perpassa a questão da construção de uma memória, que no mundo antigo encontrava-se imbricada diretamente com a constituição dos relatos. A maneira de o homem público driblar a morte física era inscrever o seu nome na memória política romana e isso era feito pelo relato de suas ações no saber histórico. No topos ciceroniano, a história era a magistra vitae, narrativa de grandes feitos, de exemplos, na constância que era identificada no devir da humanidade. Desse modo, a identidade construída a partir da memória deveria conter grandes lembranças e grandes esquecimentos. Aqueles que foram alçados a altos cargos, mas que se mostraram indignos de suas honras, podiam ser apagados da memória oficial do povo romano, a ser inscrita nos textos e nos artefatos materiais, por uma determinação do Senado. A essa prática se dava o nome de damnatio memoriae ("o apagar da memória"), pelo apagamento de todas as referências à existência daquele ser em passagem pela face da Terra. A rasura de sua existência criava uma nova memória, que reformulava a identidade que os romanos criavam de si mesmos; ao não mais existir, seus contemporâneos e seus sucessores estavam desobrigados de se lembrarem de um ser que pouco ou em nada havia contribuído

\footnotetext{
${ }^{36}$ Roger Chartier, A beira da falésia: a história entre certezas e inquietudes, Porto Alegre, Editora da UFRGS, 2002, p. 73

${ }^{37}$ Georges Balandier, O Dédalo: para finalizar o século XX. Rio de Janeiro, Bertrand, 1999, p. 112-113.

${ }^{38} / d e m$, Ibidem, p. 117
} 
para o fortalecimento do Império. Eliminar as imagens de uma pessoa, as referências à sua existência, era excluir a possibilidade de relembrar o original. ${ }^{39}$ Por isso a concessão da damnatio memoriae era um castigo tão temível no mundo romano, pois apagar qualquer referência ao morto era como deixar o seu cadáver insepulto, uma das piores coisas que poderia ocorrer com os mortos, pois sua alma ficaria sem porto, sem direção.

\section{Aqueles que foram alçados a altos cargos, mas que se mostraram indignos de suas honras, podiam ser apagados da memória oficial do povo romano}

A produção literária foi e continua sendo formadora de opiniões, de sentidos. Mesmo restrita a cânones diminutos - como nos epigramas, por exemplo, cujas principais características de formulação foram a brevidade e a síntese, ou seja, dizer-se algo importante, que merecia ser pronunciado de forma quase pedagógica, usando poucas palavras - , a arte epigramática abarcou em si profunda significação cultural. Muito se pode aprender sobre os homens do passado a partir de todos os rastros que nos chegaram. Paladas de Alexandria foi um dos últimos poetas gentios, pois escreveu sua obra no final do século IV d.C. Nela, retomou a tradição epigramística grega e pela imitatio criativa reelaborou sua realidade, apresentando uma Antiguidade tardia a partir de semiprovérbios, propondo um imaginário que ia muito além de conflitos entre cristãos e pagãos. Foi jocoso com a situação feminina: "Toda mulher desperta cólera, salvo em dois bons momentos: um quando na cama, o outro quando na campa"; ${ }^{40}$ ou: "Quem por desgraça se casou com mulher feia, vê o escuro da noite quando acende as lamparinas". ${ }^{11}$

A inutilidade de o homem se preocupar com seu próprio destino inundou suas palavras, como, por exemplo: "Muita coisa pode acontecer entre o cálice e o lábio";" ou: "Enriqueces, e daí? Quando morreres, a riqueza por acaso te seguirá ao te arrastarem para o túmulo ? No juntá-la gastaste o teu tempo de vida; não poderias pagar por ela preço mais exorbitante"; ${ }^{43}$ ou ainda: "Só isso, a vida: um instante de prazer. Para longe, mágoas. Se é tão breve a existência dos homens, que venha Baco com as suas danças, coroas de flores, mulheres. Hoje eu quero ser feliz; ninguém sabe nada do amanhã"; ${ }^{44}$ e também: "Vim nu à terra e nu irei para debaixo dela. Por que canseiras vãs se o fim é só nudez?". ${ }^{5}$

\footnotetext{
${ }^{39}$ Anthony P. Gregory, "Powerful images: responses to portraits and the political uses of images in Rome", Journal of Roman Archaeology, vol. 7, Ann Arbor, 1994, p. 80-99.

${ }^{40}$ Paladas de Alexandria, Epigramas, XI.381.

41/dem, Ibidem, XI.287.

${ }^{42}$ Idem, Ibidem, X.32

${ }^{43} / \mathrm{dem}$, Ibidem, X.60

${ }^{44} /$ dem, Ibidem, V.72.

${ }^{45} / d e m$, Ibidem, X.58
} 
De igual maneira, é digna de nota a passagem seguinte, visto que, em poucas linhas, o autor enfatiza o descontentamento romano com a crise no Império ocidental que marcava o século IV d.C.:

\begin{abstract}
Admirou-me ver, nas encruzilhadas, o brônzeo filho de Zeus, tão invocado outrora, ora por terra, e irado exclamei: 'Oh trilunar que nos guardas dos males e nunca foste derrotado, hoje tombaste.' Mas de noite, ao pé do leito, Héracles disse-me a sorrir: 'embora deus, aprendi a sujeitar-me aos tempos. ${ }^{46}$
\end{abstract}

Mesmo usando poucos recursos, os epigramas condensaram os sentimentos e as crenças de Paladas. Múltiplos foram os suportes e gêneros arrolados pelos antigos para se pensar o papel do homem e da natureza. A passagem do tempo, a relação entre sagrado e profano, os percalços da vida e as vicissitudes da morte foram temas que inspiraram vários autores. Hannah Arendt enfatiza que Heródoto, nas Histórias, informa que o propósito de sua empresa é preservar aquilo que deve sua existência aos homens, salvando os feitos humanos da futilidade que provém do olvido. ${ }^{47} \mathrm{~A}$ tarefa do historiador consistiria em fazer alguma coisa perdurar na recordação, por meio da linguagem, da palavra escrita:

A História acolhe em sua memória aqueles mortais que, através de feitos e palavras, se provaram dignos da natureza, e sua fama eterna significa que eles, em que pese sua mortalidade, podem permanecer na companhia das coisas que duram para sempre. ${ }^{48}$

A produção literária que nos chegou, em seus múltiplos gêneros e tamanhos, com suas inúmeras lacunas e conflitos, nos permite perceber que gregos e romanos entenderam história e literatura como pertencentes à mesma fonte de saber: a vida humana, com todos os seus dilemas, alegrias, decepções, erros e acertos. O homem foi, é e continuará sendo o objeto e o sujeito da produção histórica e literária antiga. Composto por narrativas que buscavam sobrepujar a morte e o esquecimento, o gênero histórico se formou a partir da necessidade humana de interpretar e entender a sua existência. As relações homem/ natureza, Homem/deuses e Homem/Homem instigavam a curiosidade dos clássicos. Para compreendê-las e/ou efetivá-las, os homens lançaram mão de todo potencial comunicativo de que dispunham à época. E nesse processo imaginaram, representaram, sonharam, bem além do que nos permite hoje a constituição da ciência histórica e as angústias da tal pós-modernidade.

\footnotetext{
${ }^{46}$ Paladas de Alexandria, Epigramas, IX.441.

${ }^{47}$ Hanna Arendt, Entre o passado e o futuro, São Paulo, Perspectiva, 2003. Sobre a relação entre história e literatura no mundo antigo e no mundo moderno, vide Rainhard Koselleck; Hans-Georg Gadamer, Historia y hermenêutica, Barcelona, Paidós, 2002; Walter Ong, Oralidade e cultura escrita, Campinas, Papirus, 1998; Paolo Rossi, O passado, a memória, o esquecimento, São Paulo, Editora da Unesp, 2010; Rosalind Thomas, Letramento e oralidade na Grécia antiga, São Paulo, Odysseus, 2005.

${ }^{48}$ Hanna Arendt, op. cit., p. 78.
} 